\title{
Agnieszka Piekutowska
}

Uniwersytet w Białymstoku

e-mail: piekutowska@uwb.edu.pl

\section{WPLYW KRYZYSU GOSPODARCZEGO \\ NA MIGRACJE MIECDZYNARODOWE \\ NA PRZYKŁADZIE UNII EUROPEJSKIEJ}

\section{THE IMPACT OF THE ECONOMIC CRISIS \\ ON INTERNATIONAL MIGRATION - THE CASE OF THE EUROPEAN UNION}

DOI: 10.15611/pn.2017.498.23

JEL Classification: F22, J61

Streszczenie: W artykule przedstawiono wpływ kryzysu finansowego w UE na dynamikę i skalę migracji w UE (zarówno obywateli państw UE, jak i migrantów spoza UE). Wykazano, że zgodnie z założeniami neoklasycznej teorii migracji, w okresie recesji, na skutek pogarszającej się sytuacji na rynku pracy, imigracja spadała, a emigracja rosła. Analiza zmian sytuacji na rynku pracy w okresie kryzysu pozwala na wyciągnięcie wniosku, że obcokrajowcy odczuwają silniej negatywne skutki pogarszającej się sytuacji na rynku pracy niż krajowa siła robocza (państwa przyjmującego). W analizie wyróżniono migrantów z państw UE i spoza UE, co pozwoliło zauważyć, że chociaż to imigranci spoza UE odczuli najsilniej skutki kryzysu, to największą mobilnością w latach kryzysu wykazywali się imigranci z UE. Można to próbować wyjaśnić brakiem możliwości wyjazdów i powrotów obywateli spoza UE do państwa przyjmującego po okresie dekoniunktury, możliwość tę mają migranci z UE przemieszczający się w ramach swobody przepływu pracowników.

Słowa kluczowe: migracje międzynarodowe, kryzys finansowy, Unia Europejska.

Summary: The aim of the paper is to analyse the impact of the financial crisis in the EU on the dynamics and the scale of migration in the EU. The impact of the labour market on immigration during the crisis was assessed with the distinction of the influx of immigrants from EU member states and from outside the EU. Statistical analysis allows to conclude that foreigners were more affected by negative effects of a deteriorating labor market situation than a domestic labor force. Additionally, it has been shown that although immigrants from outside the EU were most affected by the effects of the crisis, immigrants from EU Member States showed the greatest mobility during the crisis years. At the same time, prolonging the analysis period reveals that, in the longer term, the situation in the labor market is less likely to determine immigration to EU.

Keywords: international migration, financial crisis, European Union. 


\section{Wstęp}

Celem artykułu jest określenie wpływu kryzysu gospodarczego w Unii Europejskiej na skalę i dynamikę migracji do UE i na obszarze UE w latach 2007-2015. Asumptem do podjęcia analizy jest nieuchronność kolejnych kryzysów w przyszłości. Ukazanie wpływu kryzysu gospodarczego w państwach Unii Europejskiej na migracje w ramach ugrupowania implikuje zastosowanie analizy statystycznej. Dokonana zostanie także analiza literatury (w szczególności przegląd teorii migracji odnoszących się do wpływu kryzysu na migracje), a także przywołane zostaną doświadczenia związane z innymi kryzysami z XX w.

\section{Wplyw kryzysu gospodarczego na migracje w świetle teorii}

Próba odpowiedzi na pytanie, jak kryzys gospodarczy wpływa na migracje międzynarodowe, implikuje odwołanie się w pierwszej kolejności do teorii migracji, wyjaśniającej, dlaczego ludzie migrują (a zatem dlaczego i w jakich okolicznościach zdecydują się na powrót). Z analizy tej wynika wniosek - podnoszony już w literaturze przedmiotu - że teoria zarówno migracji, jak i rynku pracy nie wskazuje jednoznacznie kierunku wpływu kryzysu na migracje [Rogers i in. 2009, s. 3].

Analiza rozpocznie się od teorii neoklasycznej (w ujęciu makroekonomicznym), bowiem ze względu na swoją prostotę i przekonującą argumentację, w sposób doniosły ukształtowała ona powszechny sposób rozumienia migracji, a także dała koncepcyjną podstawę polityki migracyjnej wielu państw [Massey i in. 1993, s. 433]. Neoklasyczna teoria migracji zakłada, że migracje międzynarodowe powodowane są zróżnicowaniem wynagrodzeń. Zróżnicowanie te stanowi przesłankę dla przepływu siły roboczej z regionu, w którym płace kształtują się na niskim poziomie, do regionu charakteryzującego się wysokim poziomem wynagrodzeń. O ile neoklasyczna teoria migracji nie odnosi się wprost do wpływu kryzysu gospodarczego na migracje, o tyle daje podstawy do rozważań w tym zakresie. Jeżeli na skutek kryzysu w państwie przyjmującym dojdzie więc do spadku wynagrodzeń (a także zmniejszą się szanse na podjęcie zatrudnienia), to w świetle teorii neoklasycznej może dojść do zmniejszenia imigracji ${ }^{1}$. Podobnie zakłada koncepcja migracji jako bufora koniunktury (conjunctural shock absorber). Idea została rozwinięta w państwach Europy Zachodniej po II wojnie światowej i zakładała tymczasową imigrację w sytuacji niedoborów na rynkach pracy państw zachodnioeuropejskich przy założeniu, że migranci powrócą do swych państw w sytuacji spowolnienia gospodarcze-

\footnotetext{
${ }^{1}$ Jednakże zaznaczyć należy, że nie chodzi o bezwzględny poziom wynagrodzeń, lecz poziom płac w stosunku do płac w kraju pochodzenia. Jeżeli więc kryzys obejmuje zarówno państwo przyjmujące, jak i wysyłające, migracja do państwa przyjmującego może spadać bądź rosnąć, w zależności od tego, jak silnie poszczególne kraje zostały nim dotknięte i czy w konsekwencji różnica wynagrodzeń między nimi zwiększa się, czy zmniejsza.
} 
go w państwie przyjmującym (jednocześnie zwalniając miejsca pracy dla siły roboczej państwa przyjmującego). Zgodnie z koncepcją w okresie recesji gospodarczej spodziewać się można istotnego wzrostu reemigracji obcokrajowej siły roboczej i spadku napływu kolejnych imigrantów [Böhning, Maillat 1974, s. 75; Dobson i in. 2009, s. 5].

Kolejna teoria - teoria dualnego rynku pracy - podkreśla większą wrażliwość migrantów na kryzysy migracyjne. Teoria ta zakłada istnienie dwóch segmentów rynku pracy: podstawowego, charakteryzującego się stabilnością zatrudnienia, dobrymi warunkami pracy, możliwością rozwoju i odpowiednio wysokimi płacami, oraz wtórnego, cechującego się niepewnością zatrudnienia, ciężkimi warunkami pracy i niskimi wynagrodzeniami [Doeringer, Piore 1970, s. 271-272]. Miejsca pracy w sektorze wtórnym są nieatrakcyjne dla krajowych pracowników, zainteresowanych pracą stałą o odpowiednio wysokim prestiżu. Teoria dualnego rynku pracy zakłada silny popyt na migrantów tymczasowych na wtórnym rynku pracy kraju przyjmującego, który stanowi istotny czynnik przyciągający migrantów. Jednocześnie podejmowanie przez migrantów zatrudnienia na wtórnym rynku pracy - często bez umowy na czas określony i większego zabezpieczenia społecznego - zwiększa ryzyko utraty zatrudnienia i środków w czasie kryzysu.

Doświadczenia wpływu wcześniejszych kryzysów na migracje wskazują, że w sytuacji gdy kryzys gospodarczy dotyka państwo przyjmujące silniej niż państwo wysyłające - (wbrew oczekiwaniom teorii neoklasycznej i koncepcji migracji jako bufora koniunktury), znaczna część migrantów pozostaje w państwie przyjmującym. W wyjaśnieniu tego stanu rzeczy pomocna jest kolejna teoria odnosząca się do przyczyn mobilności międzynarodowej - teoria sieci i kapitału społecznego. Podkreśla ona, że migracja w nowym kierunku niesie za sobą istotne ryzyko wynikające m.in. $\mathrm{z}$ braku informacji o regionie docelowym. Ryzyko, jakie podejmują kolejni migranci, jest ograniczone dzięki informacji pozyskanej od pierwszych migrantów w ramach sieci społecznych. Przez sieć należy rozumieć więzi, jakie łączą migrantów, byłych migrantów i nieemigrantów z danego regionu pochodzenia. Poprzez zakorzenienie w sieciach społecznych jednostka ma dostęp do kapitału społecznego, rozumianego jako zasób dóbr niematerialnych i materialnych, takich jak informacja, zaufanie czy pomoc. Jednocześnie migranci w sytuacji problemowej mogą liczyć na pomoc innych członków sieci. Doświadczenia wskazują, że migranci niefunkcjonujący w ramach sieci częściej decydują się na reemigrację [Beets, Willekens 2009, s. 23].

\section{Migracje w okresie recesji - doświadczenia z kryzysów w wieku XX}

Teoria migracji nie daje jednoznacznej odpowiedzi, jak kryzys w państwie przyjmującym wpływa na skalę migracji: teoria neoklasyczna i koncepcja migracji jako bufora koniunktury zakładają spadek imigracji, jeśli państwo przyjmujące dotknie kryzys. Dodatkowo, w świetle teorii dualnego rynku pracy, migranci są bardziej 
wrażliwi na kryzys niż krajowa siła robocza. Z kolei w ramach teorii sieci i kapitału społecznego wskazane są okoliczności, w jakich migranci - pomimo pogarszającej się koniunktury - będą skłonni pozostać w państwie przyjmującym. Z powyższego względu zasadne staje się przytoczenie doświadczeń z przeszłości. W zamierzeniu analiza w tej części artykułu ma pozwolić na ukazanie okoliczności, czynników, które kształtowały migracje $\mathrm{w}$ okresie recesji, a które nie zostały zaakcentowane $\mathrm{w}$ teorii migracji.

Pouczające mogą być doświadczenia niemieckie z okresu dekoniunktury w latach 1966-1967 czy kryzysu naftowego w latach 70. XX w. Na skutek pogarszającej się sytuacji gospodarczej w Niemczech liczba zagranicznych pracowników zmniejszyła się kilkakrotnie, co było zgodne z założeniami polityki migracyjnej kraju, wykorzystującej migrację jako bufor koniunktury (Konjunkturpuffer). Regulacje prawne przyjęte $\mathrm{w}$ ramach tej polityki nie pozwalały na pozostawanie w państwie po okresie zatrudnienia, a motywowały do powrotu [Golinowska 2001, s. 25-26]. Prócz Niemiec, które wprowadziły ograniczenie możliwości zatrudniania obcokrajowców do 3 miesięcy, także inne państwa zachodnioeuropejskie - np. Francja w 1974 r. pod wpływem spadku tempa wzrostu gospodarczego i rosnącego bezrobocia wprowadziły restrykcje w tym zakresie [Duncan, Waldorf 2010, s. 4]. Wynika stąd, iż istotnym czynnikiem mającym wpływ na skalę imigracji zarobkowej w okresach dekoniunktury są regulacje w zakresie czasowości pobytu i zatrudnienia. Zaznaczyć wszak należy, iż o ile skuteczne okazały się próby ograniczenia migracji zarobkowej do Niemiec w czasie dekoniunktury, o tyle zmniejszenie możliwości imigracji zarobkowej do tego kraju spotkało się z jednoczesnym zwiększeniem napływu imigrantów w ramach możliwości łączenia rodzin².

Do podobnych wniosków skłaniają doświadczenia z kryzysu w USA w latach 30. XX w. Odnotowano wówczas niezwykle wysoki spadek napływu imigrantów z Meksyku - głównego państwa wysyłającego. O ile w latach 20. XX w. napływ meksykańskich pracowników wynosił ok. 46 tys. rocznie, o tyle w latach 30 . mniej niż 2,7 tys. Jednakże spadek napływu rozpoczął się już w 1928 r., a więc przed załamaniem z 1929 r., co sugeruje, że spadek imigracji w okresie kryzysu może być również wyjaśniany zwiększeniem restrykcji w ramach polityki migracyjnej - przyjęciem Aktu Imigracyjnego w 1924 r., który wszedł w życie w 1928 r. i przewidywał kwoty napływu imigrantów z większości państw [Papademetriou, Terrazas 2009, s. 9].

Wprowadzenie restrykcji w zakresie dostępu do krajowego rynku pracy w sytuacji recesji i rosnącego bezrobocia wymaga dodatkowego komentarza. Doświadczenia kryzysu naftowego, a także finansowego kryzysu azjatyckiego z lat 1979-1999 wskazują na ograniczoną skuteczność działań ukierunkowanych na ochronę krajo-

\footnotetext{
${ }^{2}$ Konsekwencją wprowadzania ograniczeń imigracyjnych przez tzw. stare kraje imigracyjne była także zmiana kierunków migracji. Uznaje się, choć z pewnym uproszczeniem, że kryzys naftowy z 1973 r. był punktem zwrotnym dla Włoch, które odczuły zwiększony napływ imigrantów, a w latach 70. XX w. stały się krajem imigracji netto [Colombo, Sciortino 2004, s. 53].
} 
wej siły roboczej, która - w założeniu - ma zapełnić stanowiska pracy opuszczane przez imigrantów. Okazało się, że rodzimi pracownicy nie chcą podejmować pracy dotychczas wykonywanej przez imigrantów. Rodzimi pracodawcy (np. malezyjscy plantatorzy czy tajscy rybacy), pomimo kryzysu, musieli zmierzyć się z problemem niezaspokojonego popytu na pracę. Sygnalizowało to, że gospodarki państw przyjmujących stawały się coraz bardziej uzależnione od obcokrajowej siły roboczej [Castles, Vezzoli 2009, s. 71].

\section{Wpływ kryzysu finansowo-gospodarczego na migrację w Unii Europejskiej w latach 2007-2015}

Już w 2007 i 2008 r. doszło do spadku imigracji do państw członkowskich UE, lecz największy spadek odnotowano w 2009 r. (o 608 tys. w porównaniu z 2008 r.). Największy spadek imigracji odnosił się do napływu imigrantów z państw UE (spadek o 403 tys., tj. 31,9\%, imigracji wewnątrz UE). Spadek imigracji obywateli spoza UE był niższy o 278 tys., co stanowiło 16,7\% imigracji spoza UE. Jednocześnie na względnie umiarkowany spadek imigracji do państw członkowskich UE wpływ miała zwiększona reemigracja własnych obywateli (rys. 1).

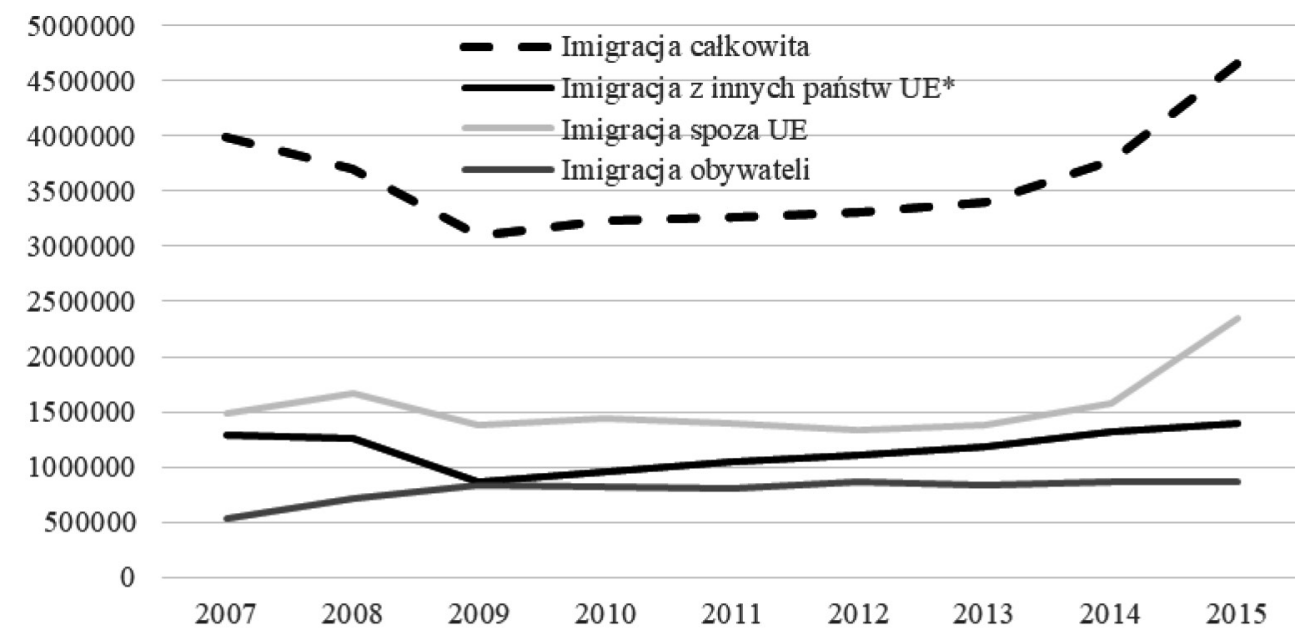

* Dla lat 2007-2012 dane dla UE-27; dla lat 2013-2015 dane dla UE-28

Rys. 1. Imigracja do UE w latach 2007-2015

Źródło: opracowanie własne na podstawie bazy Eurostatu, http://ec.europa.eu/eurostat/data/database (20.11.2017).

W 2008 r. emigracja wzrosła o prawie 600 tys., co stanowiło wzrost na poziomie 29\% w stosunku do 2007 r., przy czym wzrost emigracji obywateli innych państw 
członkowskich UE wynosił 197 tys., a migrantów spoza UE jedynie 59 tys., co stanowiło wzrost o 9,9\% w stosunku do 2007 r. (rys. 2).

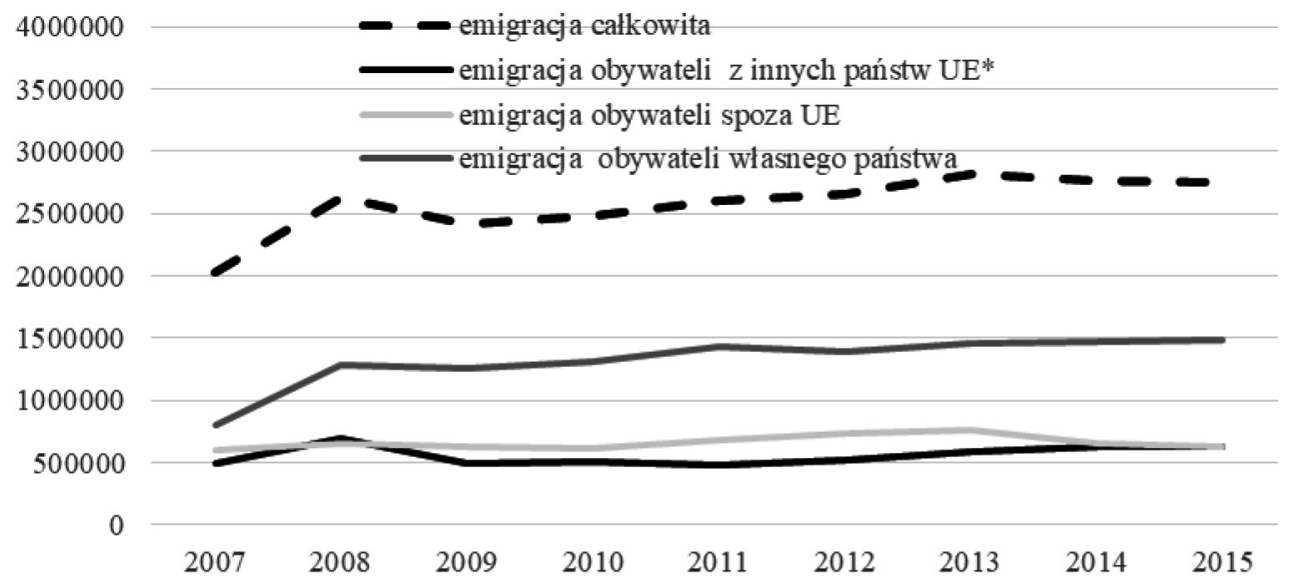

* Dla lat 2007-2012 dane dla UE-27; dla lat 2013-2015 dane dla UE-28.

Rys. 2. Emigracja z państw członkowskich UE w latach 2007-2015

Źródło: opracowanie własne na podstawie bazy Eurostatu, http://ec.europa.eu/eurostat/data/database (20.11.2017).

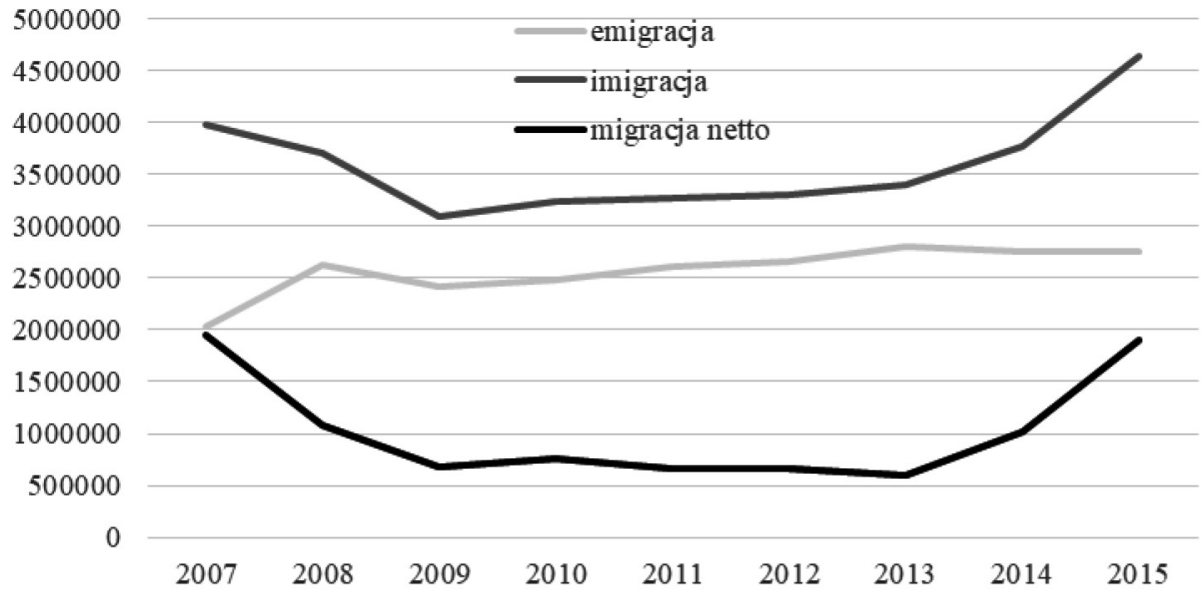

* Dla lat 2007-2012 dane dla UE-27; dla lat 2013-2015 dane dla UE-28

Rys. 3. Emigracja, imigracja i migracja netto w UE w latach 2007-2015

Źródło: opracowanie własne na podstawie bazy Eurostatu, http://ec.europa.eu/eurostat/data/database (20.11.2017). 
Pomimo spadku imigracji w latach 2007-2009 i wzrostu emigracji na przestrzeni 2007 i 2008 r. napływ imigrantów stale przewyższał emigrację i w całym analizowanym okresie (2007-2015) odczuwane było dodatnie saldo migracji w UE (rys. 3).

Konsekwencją tego, że napływ imigrantów przewyższał odpływ migrantów, był także wzrost liczby imigrantów w UE. Pomimo kryzysu zasób imigrantów w państwach UE rósł (nieznaczny spadek o 1,63\% odnotowano jedynie w 2011 r.).

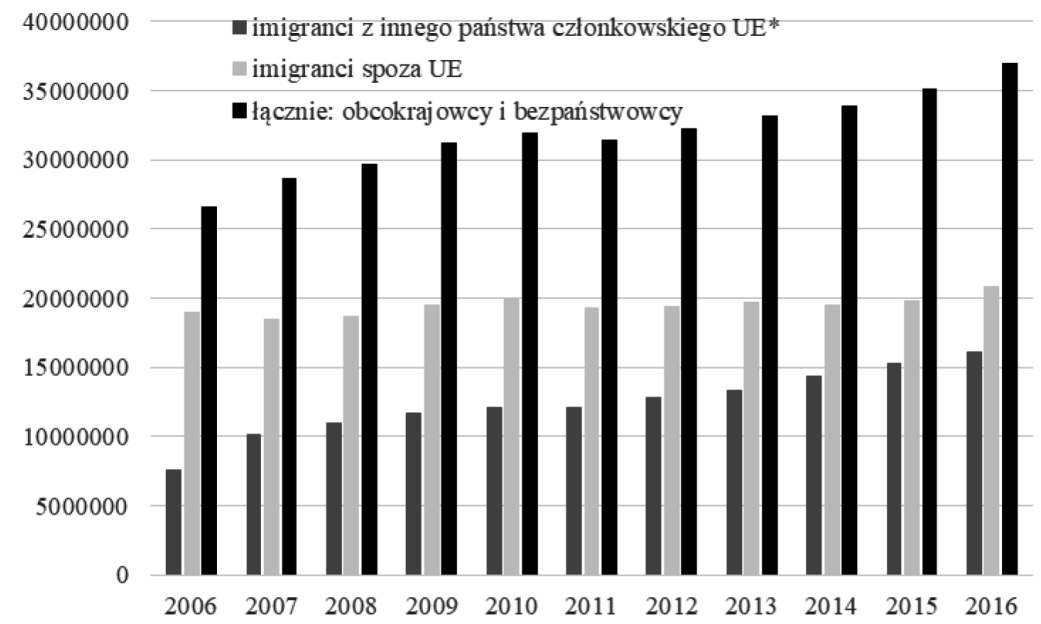

Rys. 4. Zasoby imigracyjne w państwach członkowskich UE w latach 2006-2016

Źródło: opracowanie własne na podstawie bazy Eurostatu, http://ec.europa.eu/eurostat/data/database (20.11.2017).

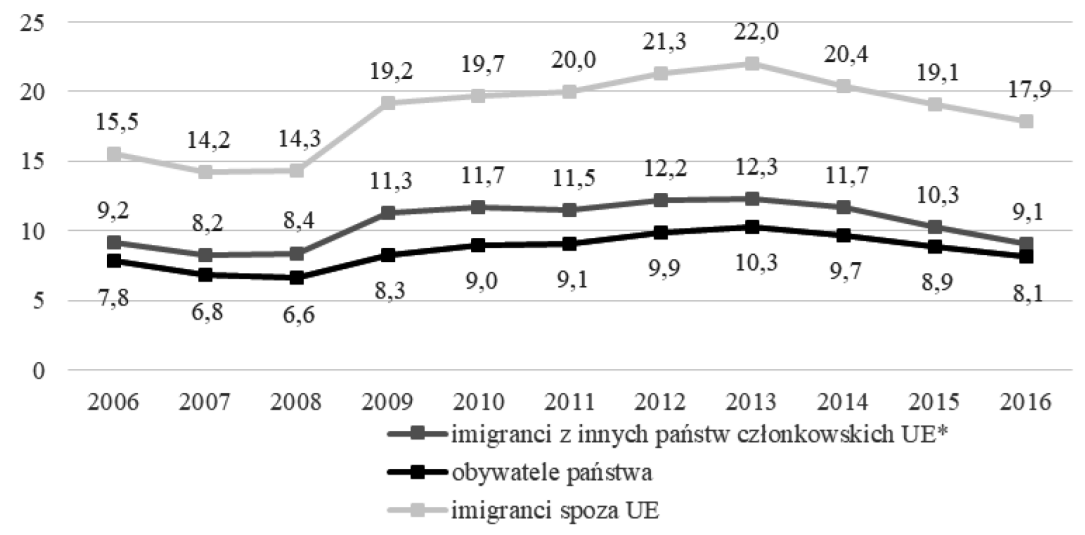

Rys. 5. Stopa bezrobocia w UE w latach 2006-2016 z wyróżnieniem imigrantów z innych państw członkowskich UE i spoza UE

Źródło: opracowanie własne na podstawie bazy Eurostatu, http://ec.europa.eu/eurostat/data/database (20.11.2017). 

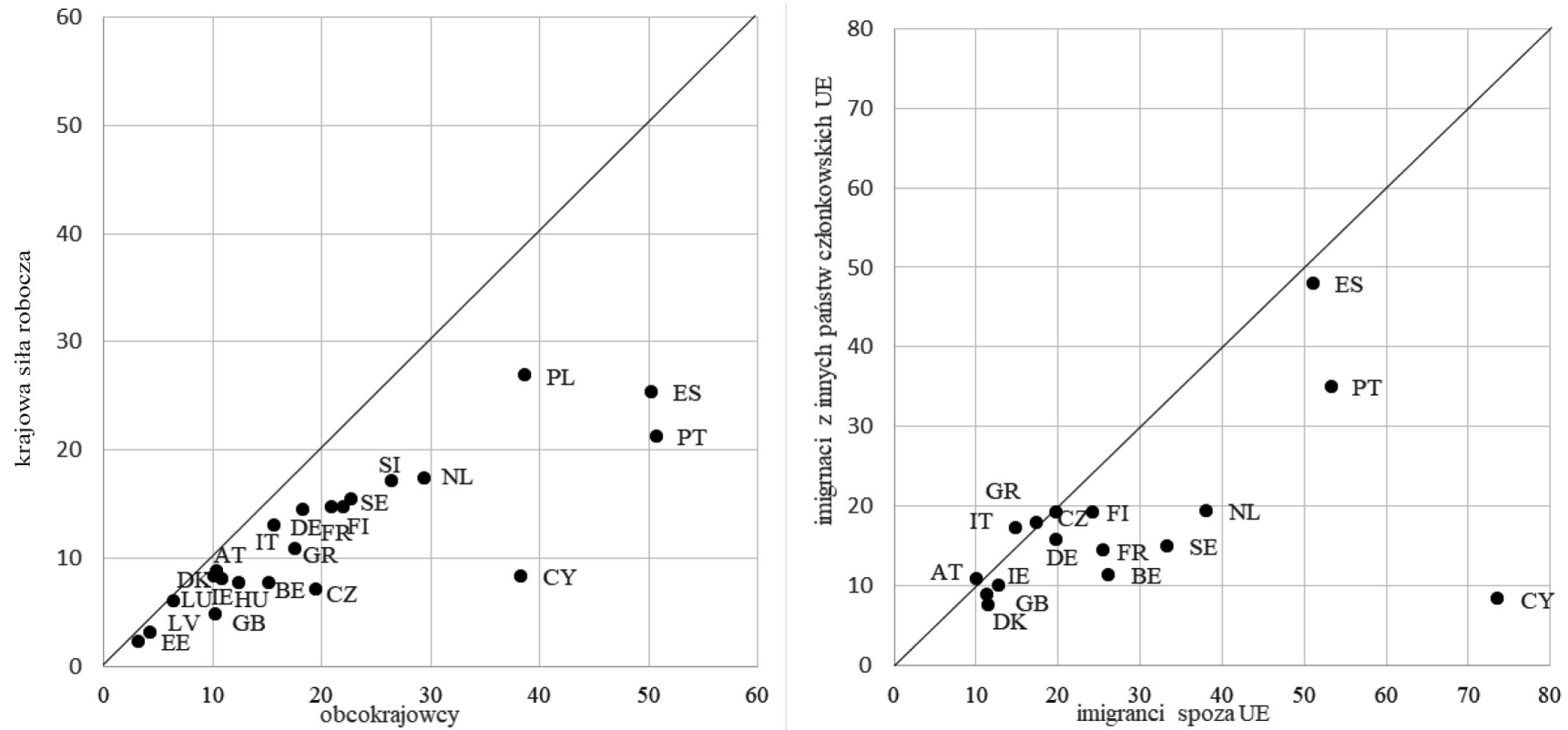

Rys. 6. Udział pracowników tymczasowych w ogóle zatrudnionych w wybranych państwach UE w 2008 r. z wyróżnieniem migrantów z UE i spoza UE

Źródło: opracowanie własne na podstawie bazy Eurostatu, http://ec.europa.eu/eurostat/data/database (20.11.2017). 
Spadek imigracji w latach 2007-2009 i wzrost emigracji pomiędzy rokiem 2007 a 2008 był konsekwencją m.in. pogarszającej się sytuacji na rynku pracy w UE, i to właśnie imigranci silniej odczuli skutki kryzysu na rynku pracy. O ile stopa bezrobocia pracowników krajowych wzrosła z 6,6\% w 2008 r. do 10,3\% w 2013 r., o tyle bezrobocie wśród pracowników pochodzących z innych państw UE wzrosło do poziomu 12,3\% w 2013 r. Najsilniej problem bezrobocia dotknął imigrantów spoza UE - w 2013 r. stopa bezrobocia wyniosła 22\% (rys. 5).

Fakt, że imigranci silniej odczuli problem bezrobocia w czasie kryzysu, wiązać można $\mathrm{z}$ wysoką koncentracją zatrudnienia imigrantów (szczególnie spoza UE) w sektorach o wysokim popycie cyklicznym, takich jak budownictwo czy handel detaliczny [Koehler i in. 2010, s. 4; Chaloff $i$ in. 2012, s. 40]. Kolejną przyczyną jest to, że są oni często zatrudniani na podstawie umów czasowych (rys. 6).

Udział zatrudnionych na umowy czasowe wśród pracowników krajowych w UE wynosił w 2008 r. 13,5\%, podczas gdy wśród obcokrajowców - 23,2\%. W szczególności udział pracowników tymczasowych był wysoki wśród imigrantów spoza UE - jedynie w Grecji, Włoszech i Austrii udział pracowników tymczasowych spoza UE ustępował udziałowi pracowników tymczasowych wśród imigrantów z UE.

Skutkiem trudnej sytuacji na rynku pracy wśród obcokrajowców była zmniejszona imigracja. Jak wynika z danych na rys. 7, bezrobocie było istotnym czynnikiem kształtującym imigrację do UE w okresie kryzysu. Pomiędzy bezrobociem a imigracją do UE wystąpiła silna korelacja ujemna $(r=-0,96 \mathrm{w}$ przypadku imigracji z UE i $r=-0,76 \mathrm{w}$ przypadku imigrantów spoza UE). W przypadku imigrantów z UE stopa bezrobocia wyjaśnia aż 92,5\% zmienności imigracji; w przypadku imigrantów spoza UE stopa bezrobocia wyjaśnia 57,2\% zmienności imigracji w latach 2007-2010.

Pomimo gorszej sytuacji imigrantów spoza UE niż imigrantów z UE, to ci drudzy charakteryzowali się wyższym spadkiem imigracji i większym wzrostem emigracji. W przypadku imigrantów spoza UE stopa bezrobocia w 2009 r. wynosiła $19,2 \%$, a udział pracowników tymczasowych $-26,2 \%$ w 2008 r. W takiej sytuacji imigracja spadła o $16,7 \%$ (na przełomie 2008 i 2009 r.), a emigracja na przełomie 2007/2008 r. wzrosła o 9,9\%. Dla porównania: w przypadku imigrantów z UE stopa bezrobocia w 2009 r. wynosiła 11,3\%, a udział pracowników tymczasowych wynosił $18,6 \%$ w $2008 \mathrm{r}$. W takich okolicznościach imigracja obywateli państw członkowskich UE na przełomie 2008 i 2009 r. spadła o 31,9\%, a emigracja 2007/2008 wzrosła o $39,5 \%$.

Zauważyć jednak należy, że powyższe spostrzeżenie dotyczy krótkiego okresu (lat 2007-2010). Wydłużenie okresu analizy pozwala zauważyć, że sytuacja na rynku pracy w mniejszym stopniu determinuje imigrację. Korelacja pomiędzy bezrobociem a imigracją do UE w latach 2007-2015 nadal przyjmowała wartości ujemne, lecz nie była tak silna (wskaźnik r-Pearsona w przypadku imigracji z UE wyniósł $-0,47$, a w przypadku imigracji spoza UE -0,19). Wskaźnik determinacji (na poziomie $\mathrm{R}^{2}=0,219 \mathrm{w}$ przypadku imigracji z $\mathrm{UE}$ i $\mathrm{R}^{2}=0,0378 \mathrm{w}$ przypadku imigracji spoza UE) informuje, że inne czynniki stają się istotne w wyjaśnieniu imigracji w długim okresie. 

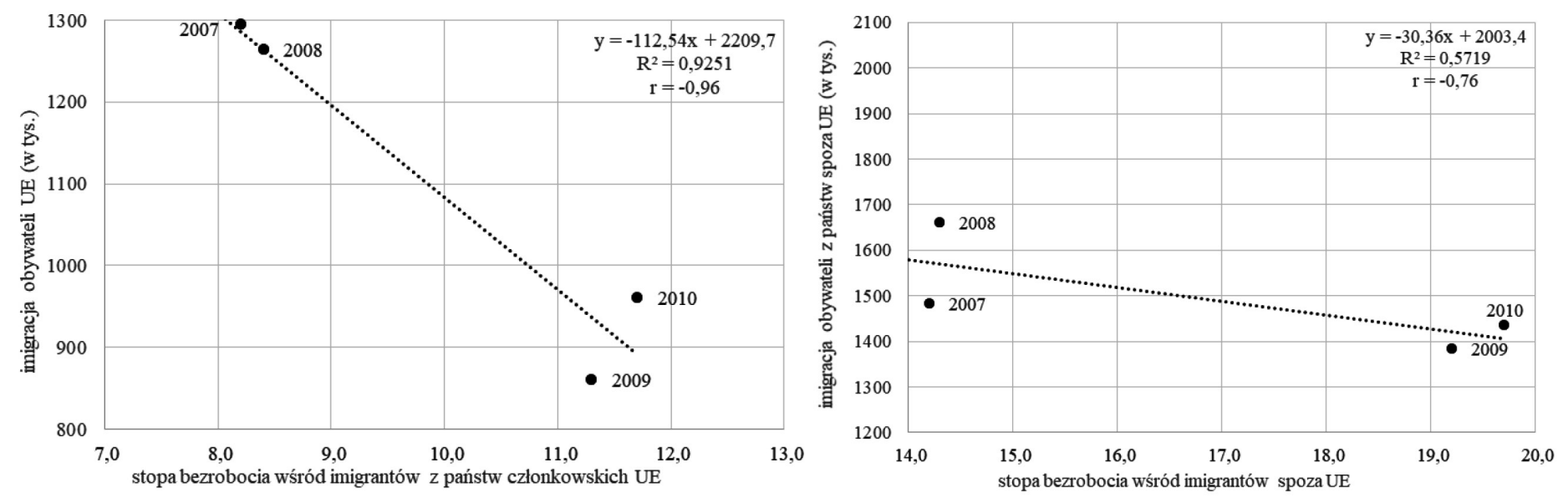

Rys. 7. Imigracja a stopa bezrobocia wśród imigrantów z państw członkowskich UE i spoza UE w latach 2007-2010

Źródło: opracowanie własne na podstawie bazy Eurostatu, http://ec.europa.eu/eurostat/data/database (20.11.2017). 


\section{Zakończenie}

Przeprowadzona analiza wpływu kryzysu na migracje w UE - choć ograniczona i skoncentrowana na sytuacji na rynku pracy - pozwala na wyciągnięcie kilku wniosków. W pierwszej kolejności stwierdzić można, że negatywne konsekwencje kryzysu na rynku pracy w UE silniej odczuli imigranci niż krajowa siła robocza. To właśnie wśród imigrantów (szczególnie imigrantów spoza UE) bezrobocie wzrosło najsilniej. W takiej sytuacji, zgodnie z koncepcją imigracji jako bufora koniunktury - w okresie recesji nastąpił spadek imigracji i wzrost emigracji. Jednakże wyróżnienie wśród obcokrajowców imigrantów z UE i spoza niej pozwala zauważyć, że spadek imigracji (i wzrost emigracji) dotyczył głównie imigrantów z innych państw członkowskich UE. Reakcja w zakresie mobilności międzynarodowej imigrantów spoza UE - pomimo najtrudniejszej sytuacji na rynku pracy - była słabsza. Przeprowadzona analiza pozwala jedynie przypuszczać, że jedną z przyczyn mniejszego spadku imigracji obywateli państw spoza UE niż z państw członkowskich UE mógł być brak informacji o sytuacji na rynku pracy w UE; z kolei ograniczone wyjazdy obywateli państw spoza UE można próbować wyjaśnić brakiem możliwości ich powrotu do państwa przyjmującego po okresie dekoniunktury, którą to możliwość mają migranci z UE przemieszczający się w ramach swobody przepływu pracowników. Odpowiedź na pytanie, dlaczego w okresie recesji nie doszło do istotnego spadku imigracji obywateli z państw spoza UE, wykracza jednak poza ramy niniejszego opracowania i skłania do kolejnych badań.

Kolejne wnioski wynikają z wydłużenia okresu analizy. Dzięki temu możliwe jest zauważenie, że spadek imigracji i wzrost emigracji były nie tylko umiarkowane, lecz także ograniczone do dwóch lat - w dłuższej perspektywie imigracja i emigracja stabilizują się, a w okresie poprawy koniunktury następuje zmiana trendu (wzrost imigracji i spadek emigracji w latach 2013-2015). Przeprowadzona analiza wykazała, iż odmiennie od krótkiego okresu, w dłuższej perspektywie nie zachodzi silna korelacja pomiędzy imigracją a sytuacją na rynku pracy państwa przyjmującego, a więc znaczenia w kształtowaniu imigracji nabierają inne czynniki. Czynnikiem takim jest m.in. polityka migracyjna państwa przyjmującego, która wraz z kryzysem ulec może zmianie: państwa przyjmujące borykające się z wysokim bezrobociem mogą zdecydować się na bardziej restrykcyjne regulacje w zakresie dostępu obcokrajowej siły roboczej do swego rynku pracy. Jednakże ograniczenie możliwości legalnej imigracji zarobkowej często wiąże się w wykorzystaniem przez imigrantów innych możliwości wejścia na rynek pracy - np. imigracji nielegalnej. Ta, ze względu na swą nieujawnioną naturę, nie została ujęta w analizie. Stąd wnioski o wpływie kryzysu na migrację do UE wymagają ostrożności i świadomości, że pozostają one ograniczone jedynie do migracji legalnych. 


\section{Literatura}

Baza Eurostatu, http://ec.europa.eu/eurostat/data/database.

Beets G., Willekens F., 2009, The global economic crisis and international migration: An uncertain outlook, Vienna Yearbook of Population Research, vol. 7, s. 19-37.

Böhning W.R., Maillat D., 1974, The Effects of the Employment of Foreign Workers, OECD, Paris.

Castles S., Vezzoli S., 2009, The global economic crisis and migration: temporary interruption or structural change?, Paradigmes: Economia Productiva i Coneixement, vol. 2, s. 68-75.

Chaloff J., Dumont J.C., Liebig T., 2012, The impact of the economic crisis on migration and labour market outcomes of immigrants in OECD countries, OECD CESifo DICE Report, vol. 1, s. 39-47.

Colombo A., Sciortino G., 2004, Italian immigration: The origins, nature and evolution of Italy's migratory systems, Journal of Modern Italian Studies, vol. 9(1), s. 49-70.

Dobson J., Latham A., Salt J., 2009, On the move? Labour migration in times of recession, Policy Network Paper, s. 1-23.

Doeringer P.B., Piore M.J., 1970, Internal Labor Markets and Manpower Analysis, Manpower Administration, Washington.

Duncan N.T., Waldorf B.S., 2010, High skilled immigrant recruitment and the global economic crisis: the effects of immigration policies, Department of Agricultural Economics, Purdue University Working Paper, vol. 10(1), s. 1-18.

Golinowska S., 2001, Teorie migracji a debata o swobodzie przepływu pracowników w rozszerzonej Unii Europejskiej, Problemy Polityki Społecznej, nr 3, s. 17-31.

Koehler J., Laczko F., Aghazarm Ch., Schad J., 2010, Migration and the Economic Crisis in the European Union: Implications for Policy, International Organization for Migration, Brussels.

Massey D.S., Arango J., Hugo G., Kouaouci A., Pellegrino A., Taylor J.E., 1993, Theories of international migration: A review and appraisal, Population and Development Review, vol. 19, no. 3, s. 431-466.

Papademetriou D.G., Terrazas A., 2009, Immigrants and the Current Economic Crisis, Migration Policy Institute, Washington DC.

Rogers A., Anderson B., Clark N., 2009, Recession, Vulnerable Workers and Immigration: Background Report, COMPAS - Centre on Migration, Oxford. 